\title{
THE METABOLISM OF THE BRAIN
}

\author{
BY \\ F. C. COURTICE \\ From the Departments of Physiology and of Surgery, Oxford \\ (ReCeIved 3Rd August, 1940)
}

IN a previous paper (Courtice, 1940) observations on the cerebral circulation in unanæsthetized subjects suffering from intracranial tumour and in cats anæsthetized with chloralose have been reported. In these experiments the arterio-venous carbon dioxide and oxygen differences have been measured with the subjects and animals lying quietly at rest, so that the respiratory quotients may be calculated, thereby giving an indication of the metabolism of the brain tissue. The methods employed have already been described in detail. The blood sugar estimations given below were made by the method of Hagedorn and Jensen (Peters and van Slyke, 1932), each determination being done in triplicate.

In Fig. 1 are plotted the arterio-venous carbon dioxide differences against
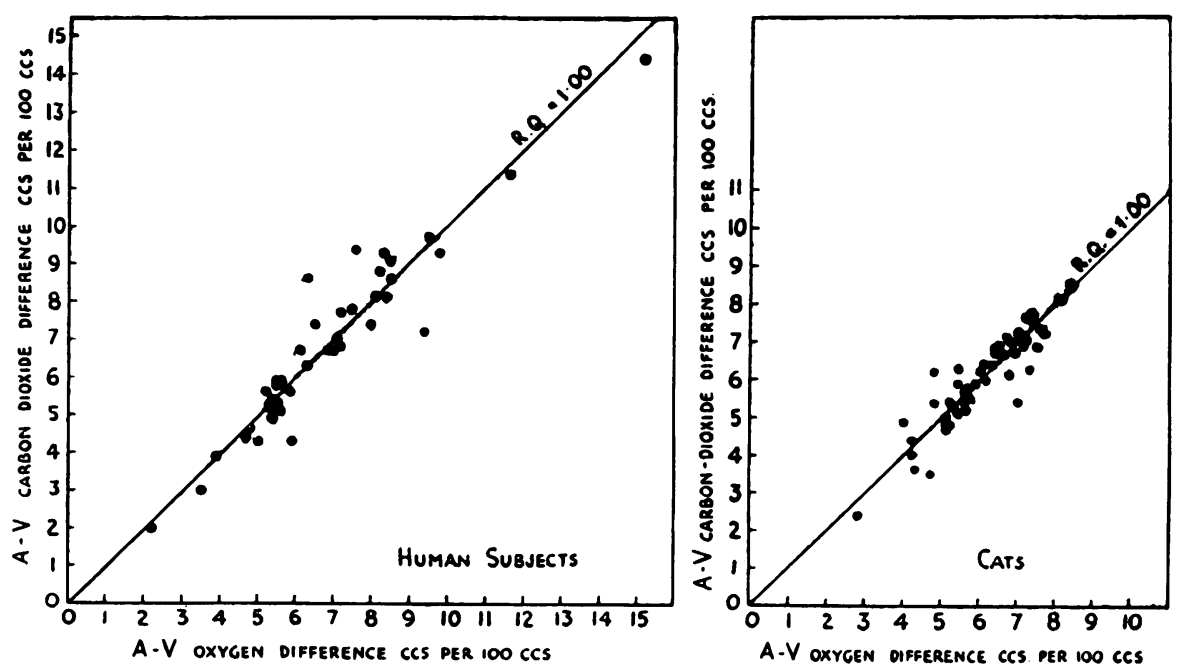

Fig. 1. - The relation between the carbon dioxide given off and the oxygen taken up by the brain, in unanæsthetized human subjects and in cats.

the arterio-venous oxygen differences in a series of human subjects (43 determinations on 30 subjects, some of whom were not suffering from intracranial tumour and had a normal intracranial pressure), and in a series of cats (50 in 306 
number). It can be seen from these observations that practically all the points lie very close to a line representing a respiratory quotient (that is, the ratio of the carbon dioxide given off. to the oxygen taken up, expressed in volumes) of unity. Of the human cases 35 and of the cats 41 determinations lie within the range of 0.90 to $1 \cdot 10$. All the cats and the majority of human cases were without food for 12 to 18 hours, the remainder of the latter being without food for several hours.

The method of measuring the carbon dioxide given off and of the oxygen taken up by the brain tissue will be true only if the blood is neither concentrated nor diluted in its passage through the capillaries, that is, if the volume of blood entering is the same as that leaving the brain in a given time. Should there be any change in the volume of blood plasma as it passes through the brain, the hæmoglobin concentration will vary accordingly. In all samples of blood taken the oxygen capacity has been measured, and the average results of these measurements are shown in Table 1. These average figures show that there is practically no difference between the hæmoglobin concentration of the blood entering and leaving the brain, while in each individual case the difference has likewise been negligible. Thus no error has been incurred by concentration or dilution of the blood in its passage through the brain tissue. Since the subjects and the animals were lying quietly at rest while the blood samples were being taken and for a considerable time before, there should be no disturbance of the acidbase balance of the blood which would upset the respiratory quotient, so that the ratio of the arterio-venous carbon dioxide difference to the arterio-venous oxygen difference should give a true indication of the foodstuffs utilized by the brain.

TABLE 1

\begin{tabular}{|c|c|c|}
\hline & \multicolumn{2}{|c|}{ OXYGEN CAPACITY, C.CS. PER 100 C.CS. } \\
\hline & ARTERIAL BLOOD & VENOUS BLOOD \\
\hline $\begin{array}{ccccc}\text { Human } & \text { Subjects: } & \text { average of } & 43 \\
\text { cases } & \ldots & \ldots & \ldots & \ldots\end{array}$ & $17 \cdot 0$ & $17 \cdot 2$ \\
\hline Cats: average of 50 cases .. & $14 \cdot 4$ & $14 \cdot 4$ \\
\hline
\end{tabular}

The average respiratory quotients of the groups of human subjects and of cats, depicted in Fig. 1, as well as of the smaller groups which were discussed in the previous paper, are shown in Table 2 . In both groups, in human subjects and in cats, the average respiratory quotient is 1.00 , which indicates that the brain is utilizing carbohydrate only, in spite of the fact that the majority of cases were without food for a considerable time, and presumably had a total respiratory quotient for the whole body of approximately $0 \cdot 80$ to $0 \cdot 85$.

That this respiratory quotient of unity really indicates the utilization of carbohydrate only has been further shown in a small group of cases, both in human subjects and in cats, by measuring the arterio-venous blood sugar differences together with the arterio-venous carbon dioxide and oxygen 
differences. The results are shown in Table 3. It can be seen that on the average the actual blood sugar difference is equal to the theoretical blood sugar difference, assuming that carbohydrate only is being used, in a group of ten cats, and almost so in a group of ten human subjects. In both groups the mean respiratory quotient is approximately unity. In one subject in whom the percentage saturation of the jugular blood was only 17 and the arteriovenous oxygen difference $15 \cdot 2$ c.c. per 100 c.c., it is interesting to note that the blood sugar difference was $20 \mathrm{mgm}$. per 100 c.c. and agreed exactly with the theoretical value.

TABLE 2

\begin{tabular}{|c|c|c|c|c|}
\hline & & $\begin{array}{c}\text { A-V CO } \\
\text { DIFFERENCE, } \\
\text { C.C. PER CENT. }\end{array}$ & $\begin{array}{c}\text { A-V O } \\
\text { DIFFERENCE, } \\
\text { C.C. PER CENT. }\end{array}$ & $\begin{array}{l}\text { RESPIRATORY } \\
\text { QUOTIENT }\end{array}$ \\
\hline $\begin{array}{l}\text { Human subjects: } \\
\text { All cases }(43) \\
\text { Frontal and parietal tumours (9) } \\
\text { Other tumours (13) }\end{array}$ & $\begin{array}{l}\ldots \\
\cdots \\
\cdots\end{array}$ & $\begin{array}{l}6 \cdot 9 \\
6 \cdot 0 \\
8 \cdot 5\end{array}$ & $\begin{array}{l}6 \cdot 9 \\
5 \cdot 8 \\
8 \cdot 3\end{array}$ & $\begin{array}{l}1.00 \\
1.03 \\
1.03\end{array}$ \\
\hline 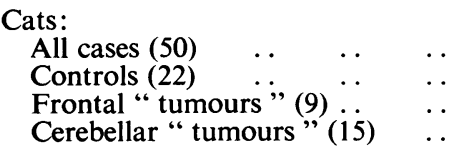 & $\begin{array}{l}. . \\
\cdots \\
.\end{array}$ & $\begin{array}{l}6 \cdot 0 \\
5 \cdot 3 \\
5 \cdot 0 \\
6 \cdot 5\end{array}$ & $\begin{array}{l}6 \cdot 0 \\
5 \cdot 3 \\
4 \cdot 8 \\
6 \cdot 7\end{array}$ & $\begin{array}{l}1.00 \\
1.00 \\
1.04 \\
0.97\end{array}$ \\
\hline
\end{tabular}

TABLE 3

\begin{tabular}{|c|c|c|c|c|}
\hline & $\begin{array}{l}\text { RESPIRATORY } \\
\text { QUOTIENT }\end{array}$ & $\begin{array}{c}\text { A-V } \mathrm{O}_{2} \\
\text { DIFFERENCE }\end{array}$ & $\begin{array}{c}\text { THEORETICAL } \\
\text { A-V } \\
\text { B.S. DIFFERENCE }\end{array}$ & $\begin{array}{c}\text { ACTUAL } \\
\text { A-V } \\
\text { B.S. DIFFERENCE }\end{array}$ \\
\hline \multirow[t]{2}{*}{ Human subjects } & $\begin{array}{l}0.96 \\
0.91 \\
0.98 \\
1.07 \\
1.01 \\
1.34 \\
1.01 \\
0.99 \\
0.77 \\
0.95\end{array}$ & $\begin{array}{r}5.5 \\
6.5 \\
11.6 \\
7.2 \\
6 \cdot 6 \\
8.2 \\
8 \cdot 5 \\
7 \cdot 1 \\
9.4 \\
15.2\end{array}$ & $\begin{array}{r}7 \\
9 \\
16 \\
10 \\
9 \\
11 \\
10 \\
9 \\
13 \\
20\end{array}$ & $\begin{array}{r}9 \\
7 \\
13 \\
8 \\
5 \\
12 \\
8 \\
10 \\
12 \\
20\end{array}$ \\
\hline & 1.00 & $8 \cdot 6$ & $11 \cdot 4$ & $10 \cdot 4$ \\
\hline Cats $\quad$. & $\begin{array}{l}0.96 \\
1.05 \\
1.03 \\
0.98 \\
0.97 \\
1.02 \\
0.98 \\
1.06 \\
0.98 \\
1.05\end{array}$ & $\begin{array}{l}7 \cdot 6 \\
6 \cdot 1 \\
6 \cdot 0 \\
6 \cdot 1 \\
7 \cdot 2 \\
6 \cdot 3 \\
7 \cdot 1 \\
6 \cdot 7 \\
5 \cdot 0 \\
5 \cdot 3\end{array}$ & $\begin{array}{r}10 \\
8 \\
8 \\
8 \\
10 \\
8 \\
10 \\
9 \\
7 \\
7\end{array}$ & $\begin{array}{r}10 \\
8 \\
4 \\
9 \\
8 \\
9 \\
11 \\
10 \\
7 \\
9\end{array}$ \\
\hline & 1.01 & $6 \cdot 3$ & $8 \cdot 5$ & $8 \cdot 5$ \\
\hline
\end{tabular}


The comparison of the respiratory quotient of the brain with other parts of the body has been made by Lennox and Leonhardt (1931) in a large series of experiments. In the present series of experiments investigations of three subjects only have been made to show that similar results are obtained by the Haldane blood gas apparatus as by the van Slyke apparatus used by most other observers. Table 4 shows the results in three human subjects of the respiratory quotients and of the arterio-venous oxygen differences, samples being taken from the brain and arm simultaneously. In these cases the respiratory quotient of the brain is approximately unity, while that of the arm is 0.81 . The theoretical blood sugar differences in two cases corresponding to these respiratory quotients and oxygen differences agree very well with the blood sugar differences actually measured. The theoretical blood sugar differences in the two observations on the metabolism of the arm have been calculated from the proportions of fat and carbohydrate used assuming that the respiratory quotient is a true indication of the foodstuffs utilized.

TABLE 4

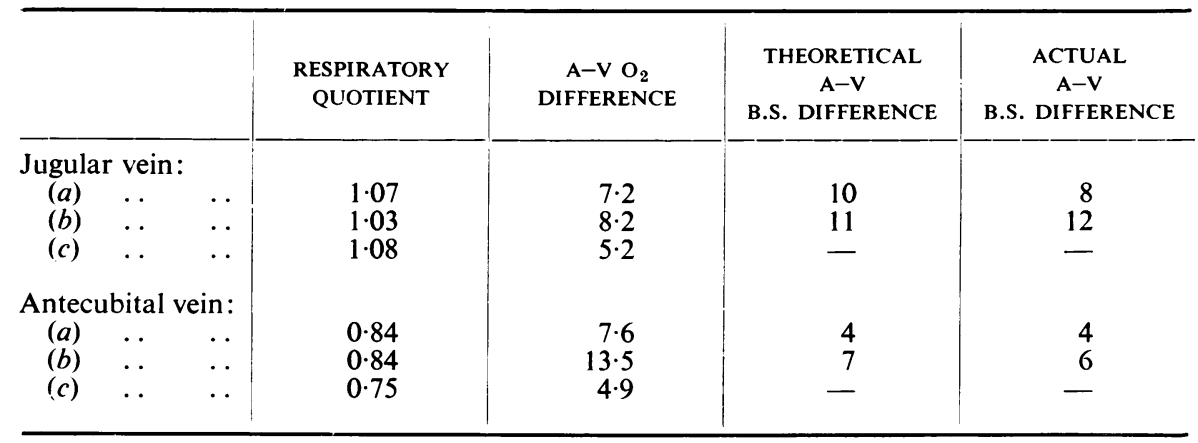

\section{Discussion}

The results described indicate that the methods employed give an accurate indication of the metabolism of the brain tissue. Previous investigations of the respiratory quotient of the brain in vivo, estimated by measuring the oxygen and carbon dioxide content of the blood entering and leaving the brain, have varied somewhat, but on the whole they have shown that the brain utilizes mainly carbohydrate. Lennox (1930) found in a series of fifty-one human subjects an average respiratory quotient of 0.90 , but in later investigations Lennox and Leonhardt (1931) found in a series of 120 cases an average respiratory quotient of 0.95 , and they conclude that the results of this series are probably more correct than the first. More recently, Williams and Lennox (1939) found in four groups of subjects average respiratory quotients varying from 0.94 to $1 \cdot 10$, although their individual results varied within the wide range of 0.05 to $2 \cdot 66$. In a small group of anæsthetized dogs, both normal and diabetic, Himwich and Nahum (1932) have shown that the respiratory quotient is $1 \cdot 00$. 
Lennox and Leonhardt (1931) have also measured the arterio-venous blood sugar differences in some of their subjects and find that the difference is much greater in the brain than in the arm and leg. They point out, however, that the arterio-venous oxygen difference of the brain is also greater than that of the arm and leg, and conclude that for this reason they are unable to relate the high utilization of sugar by the brain with its high respiratory quotient. In their table of results they do not correlate the arterio-venous oxygen and blood sugar differences, but only give average oxygen and carbon dioxide values in a large group of cases and average blood sugar values for a much smaller group of cases. It is therefore impossible to say from their figures how closely the utilization of sugar agrees with the respiratory quotient.

Chute and Smyth (1939), using the isolated perfused cat's brain, find that the theoretical oxygen consumption required for the disappearance of glucose is less than the actual oxygen consumption. It would appear, therefore, that the brain is using in these circumstances substances other than glucose.

The results of the present series of experiments show that the respiratory quotient of the brain is very constant and approximately unity in all cases. The determinations of the blood sugars taken in correlation with the respiratory quotients and arterio-venous oxygen differences indicate that the brain is utilizing carbohydrate almost entirely.

\section{REFERENCES}

Chute, A. L., and Smyth, D. H. (1939). Quart. J. exp. Physiol., 29, 379.

Courtice, F. C. (1940). J. Neurol. Psychiat., 3, 293.

Himwich, H. E., and Nahum, L. H. (1932). Amer. J. Physiol., 101, 446.

Lennox, W. G. (1930). Arch. intern. Med., 46, 630.

Lennox, W. G., and Leonhardt, E. (1931). Arch. Neurol. Psychiat., Chicago, 26, 719.

Peters, J. P., and van Slyke, D. D. (1932). Quantitative Clinical Chemistry, vol. 2, Baillière, Tindall and Cox, London.

Williams, D., and Lennox, W. G. (1939). Quart. J. Med., 32, 185. 